\title{
The influence of French colonial humanism on the study of Late Antiquity: Braudel, Marrou, Brown. ${ }^{1}$
}

\author{
Thomas E. Hunt, Newman University, Birmingham.
}

Tom Hunt is a Senior Lecturer in Theology at Newman University. His research focuses on Late Antique Christianity and its reception in the twentieth century.

Contact: Newman University, Genners Lane, Birmingham, UK. B32 3NT

t.hunt@newman.ac.uk

Keywords: Colonial humanism; Late Antiquity; Henri Marrou; Fernand Braudel; Modernity; History.

\begin{abstract}
Late antiquity is a sub-discipline of History. It is also a particular way of representing the time and space of the past. Studies in late antiquity tend to focus on the culture and society of the late Roman world. This article argues that this way of imagining time and space and people derives from Francophone debates about colonial governance that were current in the 1920s and 1930s. This colonial humanism provided the context for two Francophone authors whose work heavily influenced the formation of Late Antiquity: Fernand Braudel and Henri Marrou. This article shows how Braudel and Marrou were influenced by colonial humanism and how this influence shaped the formation of late antiquity. Historiographical accounts of the study of late antiquity have noted a recurring preoccupation with modernity. This article argues that late antiquity is modern to the extent that it is dependent on the colony for its constitution.
\end{abstract}

\section{Introduction}

Stories about past times are also stories about space, about where boundaries are drawn, and how the world might be imagined. Around 1940, as he was writing the preface to his first monograph, Santo Mazzarino, a historian of the late Roman world, reflected on his relationship to previous generations of scholarship. Enlightenment historians like Edward Gibbon had argued that the end of Roman power could best be described as a product of imperial decadence. For Mazzarino, however, this was no longer a tenable explanation.

\footnotetext{
${ }^{1}$ Research for this article was funded by a British Academy Small Grant.
} 
Indeed, he noted, this account of decadent decline seemed 'to us moderns, impossible, and therefore an analytical revision is required of the various problems which that history raises [...] and of the limits that it may imply' (Mazzarino 1942: i; Testa 2017: xi-xii). This preface captures a wider shift that was then unfolding in the way that historians analysed the history of the later Roman Empire. In the eighteenth and nineteenth centuries, the consensus was that the end of the Roman Empire and the origin of the middle ages could best be interpreted as a story of decadence and collapse. This had consequences for how historians split the past into historical periods. In the 1880s, for example, Theodor Mommsen concluded his lectures on Roman history with the sack of Rome by the Goths in 410CE (Testa 2017: x). It seemed that after this event, reported catastrophically in the written sources, one ought to draw down a tasteful scholarly curtain and wait for the Middle Ages to arrive.

This paradigm of decadence and catastrophic collapse was challenged by Alois Riegl at the turn of the twentieth century. In his Spätrömische Kunstindustrie (1901), Riegl showed that the period between the death of Constantine (337) and the crowning of Charlemagne as Emperor (800) was one of considerable aesthetic innovation, catalysed by a transformation in the ways that human beings saw and understood the world (Riegl [1901] 1985). After the 1930s and 1940s - the generation of scholarship represented by Mazzarino - it became more and more common for historians and philologists to approach the era between the third and eighth centuries as a distinct period. No longer considered merely the decayed ruins of the classical world, this period was now approached as worthy of study and one which should be analysed on its own terms. This shift in scholarship is echoed in more recent studies. For example, an introduction to a 1999 collection of essays argued that ' $\mathrm{t}$ ] he time has come for scholars, students, and the educated public in general to treat the period between around 250 and $880 \mathrm{CE}$ as a distinctive and quite decisive period that stands on its own' (Bowersock, Brown, and Grabar 1999: ix; Marcone 2008: 5), while another concludes that 'the "decline" explanation appears outmoded' (Cameron 1993, 198). Dividing the past up into periods is always an exercise in ascribing value to things; as historians rejected the utility of decadence or decline as an explanatory factor, so they redrew the boundaries of their periodization.

Late antiquity is the name given in English to this period, stretching from the mid-third century to the reign of Charlemagne. In Anglo-American scholarship, the identification of late antiquity as a specific period was the collective work of a generation of scholars who came of age in the 1960s. In his 1971 book The World of Late Antiquity, Peter Brown set out the geographical scope of this new period: 
'We live round a sea,' Socrates had told his Athenian friends, 'like frogs round a pond.' Seven hundred years later, in AD 200, the classical world remained clustered around its pond: it still clung to the shores of the Mediterranean. (Brown 1971: 11)

Later on in life, Brown observed that the identification of 'late antiquity' in his own work was caused by a shift in geographical perspective: in the 1960s he had been a historian of the western half of the late Roman Empire but towards the end of that decade he turned to the eastern Mediterranean, focusing on sources written in Greek and Syriac. As it emerged in Anglophone scholarship, and particularly in Brown's work, the geographic scope of late antiquity was the territory occupied by the Roman Empire, with a specific interest in Africa and the Middle East. Late antiquity is a particular period, defined by temporal limits, but, when Brown first spoke of it in the early 1970s, it was also a particular space: the Mediterranean basin, North Africa, and the Middle East.

As well as naming a particular time and a particular space, studies in late antiquity also developed a coherent set of methodological predispositions. As many have noted, chief among these is a turn towards the social life of human beings as it was captured in hagiography, in sermons, in material culture, or in art. Religion is understood as part of this life; it is approached and defined as a manifestation of social tensions and anxieties that played out across the Mediterranean. Part of what helped Late Antiquity to emerge as a cohesive discipline is a sense that, across the time and space, this late antique world was 'held together' by a common culture (Brown 1983: 1). Studies in late antiquity, as they emerged in Anglophone scholarship in the 1970s and 1980s, accessed sources in new ways, reading them with innovative methods, to understand the social and cultural life that bound together the humans around the edges of the Mediterranean. The term 'late antiquity' denotes a particular time, a particular place, and a particular way of knowing and imagining the people who lived in that time and place.

As one commentator has noted, this study of the later Roman Empire has been 'dominated' by the work of Peter Brown (Markus 2009: 2). Beginning in the 1960s with studies of Roman Africa and Italy, Brown combined two historiographical traditions (Brown 1961b; 1961a). The first was an Anglophone focus on the social and economic trajectories of the late Roman world, exemplified in the work of A. H. M. Jones and Michael Rostovzeff. This was complemented by a deep knowledge of the French scholarship on the early history of the Church and post-1945 philological studies of Latin (Markus 2009: 5; Wood 2013: 306-307). 
The cultural and intellectual history pioneered by his teacher, Arnaldo Momigliano, was also a significant influence on his work. Brown was able to situate familiar figures like Augustine of Hippo within a much richer account of the social and cultural life of the late Roman Empire. The study of late antiquity remains heavily focussed around Brown's 'preoccupations: the body and society, asceticism, sexuality, the evolution of Christian sensibilities, the exercise in authority within Christian Roman society [...] and death and the other world' (Markus 2009, 12).

Brown has discussed the development of his model of late antiquity in a number of places (Brown 1988, 1997, 2003). He has shown how this rendering of the late Roman world emerged as a result of reading the preceding generation of scholarship, the work produced by Mazzarino and his peers. Chief among the influences that Brown names are Fernand Braudel's La Méditerranée et le monde méditerranéen à l'époque de Philippe II (1949) and a collection of texts by the French historian Henri Marrou, including the 'Retractatio' he published in his 1949 edition of Saint Augustin et la fin de la culture antique and his Histoire de l'éducation dans l'Antiquité (1948). These studies, published in the years after the Second World War, provided Brown with the imaginative raw materials to rework the history of the late Roman world into an account of late antiquity, something at once so alien and so familiar.

In the introduction to his 1971 book The World of Late Antiquity, Peter Brown places the historian's imagination as a central concern of this new World he's unfolding before them.

[...] the writings of men like Plotinus and Augustine surprise us, as we catch strains as in some unaccustomed overture - of so much that a sensitive European has come to regard as most 'modern' and valuable in his own culture (Brown 1971: 7).

The quotation marks around the word 'modern' are striking. This punctuation serves to draw the reader's attention to this word but also to render its meaning more obscure (Cooper 2005: 113). Do the quotation marks indicate that the 'modern' is not really modern, but simply the Late Antique living in the present? Are they supposed to lend the sentence a sense of irony, undermining the word 'valuable' that follows closely behind? Do they indicate a technical term-of-art, making a connection to musical modernism evoked by the 'unaccustomed overture'? Or, and this is the position adopted in this paper, perhaps these quotation marks serve to draw our attention away from things in this text that are uncomfortable or dangerous. For there are two words in this passage that are also very important for Brown's analysis of 
late antiquity, and those two words are: 'European' and 'culture'. Perhaps these quotation marks are symptoms of something repressed that nevertheless makes itself present in Brown's writing and the historian's imagination.

This article argues that 'late antiquity' as it emerges in Anglo-American scholarship of the 1970s and 1980s replicates ways of thinking about time, space, and human beings that were current in the French Third Republic. Late antiquity is a way of thinking about time, particularly the relationship between the Roman world and the modern. It's a way of thinking about space, particularly the space of the Mediterranean, North Africa, and the Middle East. And it's a way of knowing other human beings, particularly through their culture. This division of time and space, together with the focus of culture, is also present in the development of colonial humanism in France after the First World War. The article argues that this is not a coincidence, but derives from the reception of French scholarship by English-speaking historians. In particular, Fernand Braudel and Henri Marrou have both been identified as having critical and formative influences on the work of Peter Brown. These two French historians were themselves shaped by their experiences as French men between the two world wars. Similarities between colonial humanism and late antiquity are not accidental. Rather, they indicate a fundamental isomorphism that lies unacknowledged but detectable in the marks it leaves around the word 'modern'.

To make this argument, I'm going to move through three stages. First, I open the argument by considering the different ways in which historians imagine the past, focussing on how the past might be figured as present when historians do History. I integrate this analysis into an account of French colonialism in the 1930s, particularly the connection between imperialism and knowledge production that came to be called colonial humanism. In this particular historical context, a specific definition of modernity was deployed to order and know the subjects of the French empire; to speak of modernity at this moment therefore also meant speaking of coloniality. In the second section, I show how Brown took from Braudel a deep appreciation of the role of the Mediterranean as a bridge between Africa and Europe. I argue that this geographical imagination was part of a wider way of conceptualising the space and time of the French empire. In the final section, I turn to the work of Henri Marrou. I show how Brown took from Marrou a particular understanding of culture and education that heavily influenced his work. I then argue that Marrou's model of culture was developed in the midst of wider debates about culture, civilizational collapse, and colonialism that moved through France in the 1920s and early 1930s. Braudel and Marrou gave Brown the 
intellectual raw materials to imagine the time, space, and people of the late antique world. This was, however, an imagination shaped by the colonial modernity of the Third Republic.

\section{Modern: History as present and 'colonial humanism'}

Dividing the past into periods is a work of the imagination. It is a way for historians to make sense and give meaning to the past as they encounter it. As he glanced back over preceding scholarship, Mazzarino argued that the Enlightenment model of decadent decline was no longer acceptable to 'to us moderns' [a noi moderni] (Mazzarino 1942: i). Echoing Mazzarino's words, one commentator has argued that the development of late antiquity has been animated by a 'rhetoric of modernity' (Giardina 2013: 3): the circumscription and identification of late antiquity goes hand-in-hand with wider claims about the nature of modernity. This is certainly an astute observation. Alois Riegl's analysis of late Roman material culture, for example, situated itself alongside two aspects of contemporary Viennese culture: the institutional growth of museums in the city and the wider political and aesthetic shifts ushered in by the avant garde (Cordileone 2014: 10-12). Riegl's work was also the product of the imperial ambitions of Austria-Hungary (Elsner 2002; Olin 1994). Similarly, the focus on cultural change and slow transformation that is a recurring theme of AngloAmerican treatments of late antiquity has been connected to wider twentieth-century anxieties about crisis and catastrophe (Marcone 2008). It is 'a strikingly optimistic reading of the period' (Wood 2013: 309). Some studies have argued that the focus on commonalities of

culture reproduces a commitment to multiculturalism in the liberal, Western academy (James 2008; Liebeschuetz 2001b, 2001a, 2003). In each of these cases, the nature of modernity, its location, and its historical development is conceptualised differently; each offers a particular way of representing the past and of explaining the relationship between that past and the present (Cooper 2005: 149). This seems to be a particularly strong strain in the historiography of late antiquity: '[i]f all history is contemporary history, this is currently true of one history in particular, namely that of Late Antiquity' (Giardina 2013: 4). Attempts to represent and understand the end of the Roman Empire are therefore intertwined with questions about what it means to be modern.

To study late antiquity is to study the imaginative world of people in the distant past, but it is also to think about how that past is imagined by historians. Towards the end of his essay, 'Nietzche-Genealogy-History,' Michel Foucault remarks that the nineteenth-century experience of ruin-gazing led to the emergence (Entstehung) of History as a discipline: 'cities in ruin and enigmatic monuments are spread out before us; we stop before gaping walls; we 
ask what gods inhabited these empty temples' (Foucault 1977: 92). ${ }^{2}$ Writing around the same time, the great historian Arnaldo Momigliano wrote that, '[f]rom the eighteenth century onward we have been obsessed with the Fall of the Roman Empire: this fall has become the archetype of every decline and, therefore, the symbol of our fears' (Marcone 2008: 7-8). As Foucault and Momigliano both recognised, the study of history is governed and shaped by the anxieties of the historian (Foucault 1977: 76-77).

The question of how the past remains or becomes present has influenced recent studies of historical theory that have challenged or sought to nuance the representational turn in historical studies inaugurated by Hayden White's Metahistory (Icke 2011: 131). Eelco Runia has adapted the concept of parallel processing to describe how the past becomes present in the work of historians. Parallel processing is a term used in psychotherapy training to describe a moment when processes that emerged in meetings between a therapist and client are displaced in to the meetings with the therapist and her supervisor (Runia 2014: 20-23). Runia argues that the work of historians can become animated by a similar dynamic; historians can 'repeat the problems' they are studying, as Dominic LaCapra has put it (2001: 142).

Runia's example of this process is the large report produced by Dutch historians in the wake of the Srebrenica genocide in July 1995. In his analysis, this report repeated both the wider anxieties within Dutch society around the role of the Dutch military in the massacre and the tensions between different parts of the Dutch establishment (the civil service, the military, the media, the government) (Runia 2014: 27-34). The official report that historians produced to analyse Dutch actions in the time before and during the events of summer 1995 was, in Runia's words, 'a genuine, local, and comprehensive [...] manifestation of unconscious identification processes' (Runia 2014: 46). In its refusal to reach a clear account of events, the report repeated the widespread confusion caused by Srebrenica in Dutch society. Moreover, argued Runia, the manner in which the historians had conducted their investigation also replicated the experiences of the soldiers they were studying; the historians considered themselves a lone outpost, the guardians of the society in which their small group was located. Contemporary anxieties caused by the massacre and the role of the Dutch soldiers are displaced into the study of the historians. Historians work with the imagination, but that imagination is trammelled by its own fears, projections, and refusals.

\footnotetext{
${ }^{2}$ I take the notion of ruin-gazing from some recent work on the reception of ruins in modernity (DeSilvey and Edensor 2012: 2; Hell 2009: 291).
} 
Runia and Foucault share a sense that written history functions to occlude the material and power relationships that drive change in human societies. The realism of historical narrative disguises its nature as a representation of the world. Although 'History, with a capital H, [...] cannot tolerate otherness or leave it outside its economy of inclusion' (Young 1990: 5), the smooth totality of historical narration is disrupted by those moments in which the past refuses to be disciplined. There is a similarity here to the modernist novel as it emerged in the decades before the First World War. In these novels, as Frederic Jameson has shown, descriptions of travel infrastructure (railways, roads) are important parts of the establishment of verisimilitude, but they also indicate a world beyond the space narrated by the novel (Jameson 1990: 52-53). The train track continues to an unknown station; the road winds into the distance. In Jameson's reading, these elements in the text point to a wider transformation in the European societies which produced the novels. That is, the realist descriptions of space in these novels are determined by a wider shift in the spatial organisation of imperial economies,

for colonialism means that a significant structural element of the economic system as a whole is now located elsewhere, beyond the metropolis, outside of the daily life and existential experience of the home country, in colonies over the water whose own life experience and life world - very different from that of the imperial power - remain unknown and unimaginable for the subjects of the imperial power [...]. (Jameson 1990: 50-51)

The European modernist novel is therefore the product of a dilemma: how to represent a world which is constituted by its relationship to the unknown and unimaginable other of the colony. The daily life of European states remains 'radically incomplete' because it is dependent on that which is geographically and ontologically outside itself (Jameson 1990: 58). In this situation, the modernist style emerges as a response to the representational crisis catalysed by an imperial world-system. For Jameson, breaks in the totality of realist representation of the world are determined by the spatial and economic order of imperial states.

In different ways, Foucault, Runia, and Jameson all challenge the naïve assertion that the historian represents the past to the present. For Runia and Jameson, breaks or lacunae in the totality of the historical narrative indicate deeper crises in the representational regimes determined by the social and cultural context in which the historian works. This is 
particularly the case, as Momigliano understood, with the history of the later Roman Empire. Enlightenment accounts had analysed the later Roman Empire in terms of imperial decline from classical heights, while twentieth century historiography had slowly shifted towards interpreting the period as distinct in its own right. Claims defining something in relationship to the category of 'the modern' always involve a wider set of assumptions about representation and temporality (Cooper 2005, 149). When Brown declared, then, that there is something 'modern' about Augustine and Plotinus, he was drawing on this trajectory in the historiography. Braudel and Marrou were critical sources as Brown began to reframe the time and space of the later Roman Empire but these authors were themselves part of a wider debate about the nature of modernity that unfolded in France and its overseas territories during the early twentieth century.

There was never a time when the French Republic was not also an imperial state. Fundamental to the Republic were the contradictions between republican ideals of universal equality and an imperial reality of material exploitation and violence. In the 1920s and 1930s, 'colonial humanism' became the principal way in which French politicians, administrators, and academics articulated the relationship between metropolitan France and its overseas territories.

In France, the professionalization of the study of human societies and cultures was a process intertwined with colonial government during the Third Republic (Debaene 2014: 26-27; Conklin 2013: 193-194). Young university disciplines asserted their scholarly bona fides by positioning themselves as a 'new humanism'. This rhetorical turn evoked the scholarship of the Renaissance and implied a long pedigree. It also positioned the new disciplines as a check against the inhumane alienation that accompanied the social division of academic and industrial labour (Debaene 2014: 120-124). In this way, it was argued, the professional study of other peoples and societies could address the deleterious effects of imperial capitalism and hence inform a more humane (and therefore efficient) colonial policy (Wilder 2005: 49-50). Colonial humanism was born from the exchanges between the colonial field and the universities of the Métropole (Sibeud 2002: 188-189). By the 1930s, this humanism had suffused the Humanities, structuring academics' analysis of societies and behaviours (Debaene 2014: 121-123; Reynaud Paligot 2006b: 9). This was a way of incorporating the time and space of the French empire into wider narratives of social evolution and progress. 
Emerging from the intersection of Enlightenment models of civilizational progress and the evolutionary biology of Darwin and Lemarck (Reynaud Paligot 2006b: 2), colonial humanism insisted on the fundamental equality and dignity of all human beings and so situated itself firmly within French Republican traditions. At the same time, it deployed a governmental structure that denied citizenship rights to some people in some places. To ameliorate this contradiction, colonial humanists argued that 'culture' constituted the key difference between peoples, a racialization informed by late nineteenth-century models of evolution and human change (Sibeud 2002: 21; Reynaud Paligot 2006a: 33-43). It was a shift from biological accounts of racial difference into differentiation according to culture and a society's position on a developmental axis that stretched from nomadism to nationhood (Hannoum 2008: 102-103). The universality of republican rights was not in question, but cultural differences meant that some peoples were unready to exercise effectively their rights of citizenship and autonomy (Wilder 2005: 124-129). This was a play between the universal and the particular that was common in colonial humanism (Wilder 2005: 11-15). As Carole Reynaud Paligot has put it:

Le différencialisme racial légitime ainsi la politique discriminatoire mise en œuvre dans les colonies par les gouvernements français : l'exclusion des droits civils et politiques, le régime de l'indigénat, le refus de leur accorder le droit du sol, etc. [...] Accorder droits et libertés à des peuples n'ayant pas la maturité suffisante pour en faire usage reviendrait à les rejeter dans la barbarie et l'anarchie ... (Reynaud Paligot 2006b: 6).

Colonial humanism therefore advocated the worth of all cultures and peoples as it deployed a ruthless geography of differentiated rights, deferring the conferment of full citizenship until cultures were ready to assume their humane birth right. In this context, being or becoming 'modern' was a way to make political claims to rights and representation (Cooper 2005: 146147). Championing its sensitivity to cultural difference and orientating those differences around a European 'modern', colonial humanism was an ordering of time and space and people.

Histories of late antiquity are animated by a rhetoric of modernity. This is partly because, as Momigliano pointed out, notions of decline, rupture, and barbaric futures are also common ways to define modernity. Naming something as modern establishes particular temporal relationships between the past and the 'now', shaping how the past is represented in that 
present (Cooper 2005: 149). Linear accounts of historical change function to historicise the past, presenting it as present only through its mediation by the historian. Despite this, breaks in the totality of the historical account show how History works to hide the conditions of its production. Brown opens The World of Late Antiquity by focussing on the imaginative life of his readers: the modernity of Augustine and Plotinus is defined through their relationship to a European present which is both sensitive and cultural. In this short passage, Brown deploys a very particular ordering of time, space, and people. Certain people - Augustine and Plotinus - are considered 'modern' by virtue of their relationship to European culture. Brown's introduction therefore sets up some implicit isomorphic parallels between his vision of the late antique past and the imperial imagination of French colonial humanism. Both posit culture as the fundamental defining characteristic of the world they envision. Each situates that culture in a temporal structure that is orientated around a 'modernity' conceived of as European. In the following sections I'll consider where this isomorophic relationship comes from, showing how Brown's concept of late antiquity is indebted to previous generations of Francophone scholars, whose own work was conducted during the period of colonial humanism. Colonial humanism remains present in the spatial and temporal structures that shape the study of late antiquity and in the rhetoric of modernity which animates the discipline.

\section{European: Braudel's Mediterranean in the 1930s}

The legacies of French colonialism made their way, unrecognised, into Brown's reading, their presence detectable in the symptomatic slippage between the three words, 'modern', 'European' and 'culture'. Let me offer an example of what I mean. Brown's book on Augustine was published in 1967 and The World of Late Antiquity was published in 1971 (Brown 1967, 1971). These two books show significant differences of methodology and subject matter. In the 1960s Brown had been a historian of the Latin West, but in 1971 his focus was the eastern Empire. The key to this shift was Brown's reading of Fernand Braudel's giant work on the Mediterranean in the time of Philip II, a book which, as Brown says, 'suddenly bathed the coastlines of the late antique world, endowing them [...] with a warmth, with a concreteness and with a tenacity that seemed rooted in the long rhythms of the landscape itself' (Brown 1997: 16-17). Under this inspiration, Brown presented the world of late antiquity as a specific space, focussed around the Mediterranean. The World of Late Antiquity opens with a brief account of the ways that the land and sea provided the structures and boundaries of life in the late Roman world (Brown 1971: 7). As Brown puts it: 
It is the extraordinary tide of Mediterranean life that strikes us about this empire at its apogee in the second century $\mathrm{AD}[\ldots]$ One of the main problems of the period from 200 to 700 was how to maintain, throughout a vast empire, a style of life and a culture based originally on a slender coastline studded with classical city states. (Brown 1971: 11)

Braudel's Mediterranean became the focus of Brown's new world.

Braudel himself remarks that his attitude to the Mediterranean was probably a result of his experiences in Algeria (Braudel 1999: 493). The French colonisation of Algeria precipitated a transformation in the ways that the Mediterranean was imagined. What had once been understood as a limpid barrier dividing Europe from Africa came to be imagined 'as an interval with a broader space, that of the French empire' (Blais and Deprest 2012: 52). This transformation was complemented by studies of the historical past, particularly archaeology (Ford 2015). The Roman past of North Africa was tied to the Roman past of France and so the two regions could be linked by a common patrimony. French presence in North Africa could therefore be justified as a continuation of an ancient relationship (Lorcin 2002). Braudel himself noted that Henri Pirenne was a key influence on his understanding of the Mediterranean, but his account of the Mediterranean was also one iteration of a much longer tradition of French historiography, rooted in the shifting imperial imaginary (Strachan 2011; Braudel 1999). Brown doesn't make very much of Braudel's methodological reflections on time and geography. Rather, Braudel gave him the means to see the Mediterranean as a single whole. The world of late antiquity became imaginable as a distinctive whole when Brown began to see the fundamental contiguity between the coastlines of the Mediterranean. This idea was taken from Braudel, but it had its roots in a French historiographical tradition which tried to articulate the historical relationship between France and its colonies in North Africa.

The close links between colonial humanism and the 'human sciences' are visible in the historiography of late Roman North Africa produced under the Third Republic. For example, in his 1927 study of the impact of the Arab invasions of North Africa, Les siècles obscurs du Maghreb, Emile-Félix Gautier interpreted the history of late Roman and early Islamic Africa through the prism of cultural difference (Gautier 1927). Gautier's work was predicated on dismissing the 'local knowledge' provided by Arab historians like Ibn Khaldun in favour of a more scientific analysis of the past (Hannoum 2008: 104). Romans, he said, had brought plenty and prosperity to North Africa because they knew how to work the land as farmers. In 
line with a number of contemporary studies, Gautier argued that the arrival of Arabs in the region also meant the decline of agriculture in favour of a lifestyle of delocalised nomadism. This was a common motif in French accounts of the North African past (Davis 2007: 22-23). As Abdelmajid Hannoum has observed, however, '[t]he narrative of race struggle is not absent from such a discourse. However, it is slightly changed to introduce what one might call "culture struggle"' (Hannoum 2008: 105). The differentiation of humans was accomplished through reference to differences of culture.

In its focus on cultural difference as a way of explaining historical change, Gautier's work fits within the wider tradition of colonial humanism. Colonial humanism rested on a number of presuppositions about the nature of historical change and human perfectibility (Reynaud Paligot 2006b). Historians drew on these wider models of progress and humanness as they sought to explain the events of the past and their relationship to modernity. Moreover, the construction of the time and space of the colony began as a specifically epistemological position: a denial of the validity of 'local knowledge' in favour of the universally applicable methods of the European historian (Mignolo 2002: 59). In this way, the production of History was enfolded into what Wilder calls 'colonial humanism's administrative scientific complex' which guided the Third Republic (Wilder 2005: 61). Defined in its relationship to this North African past, sustained by the knowledge production of ethnographers, historians, geographers, and archaeologists, French modernity of the 1920s and 1930s was a colonial modernity (Hannoum 2010: 222; Mignolo 2000: 22; Quijano 2007: 172-174).

Gautier's analysis of the end of Roman power in North Africa had a significant impact, as can be seen from the extended discussion of his work in Braudel's review of Charles-André Julien's Histoire de l'Afrique du Nord. This review was published while Braudel was still struggling towards the central theses that would animate La Mediterranée, but it already shows some key elements of that later work (Daix 1995: 99). In this review, Braudel refers to two monographs produced by Gautier: Les siècles obscur du Maghreb and his book on Vandal Africa (Gautier 1932), focussing on the former. This book is particularly remarkable, he says, for the author's use of cartography. For the historian, maps are 'a difficult weapon to handle, but indispensable and of the first order [une arme difficile à manier mais indispensible et de premier ordre]'. Gautier has used them, Braudel notes, to show that the neat events of the Arab chronicles and the careful reasoning of Ibn Khaldun are shaped by the geography of the Maghreb (Braudel 1933: 42). Gautier's careful use of maps has therefore revealed the extent to which the past recounted in his sources has been shaped by this 
landscape. This, he remarks, sets Gautier's work apart. From now on, all historical studies of North Africa will be defined by their relationship to this work (Braudel 1933: 42). For Braudel, the importance of Gautier's study lay in the way it conjoined the events of the past with the locality in which they took place (Deprest 2010). Seen in this context, the histories produced by Ibn Khaldun and 'les chroniqueurs arabes' are local phenomena determined by local topography; in contrast, Gautier's text produces a universal history, one which opens out a new future for historical studies. Braudel's position here is epistemological: to know about the past, one must be able to situate that past within a wider universal account of how the development of particular peoples is determined by their local geography and climate. As commentators observe, this review shows the extent to which Braudel was already in 1933 thinking about the close connections between geography and historical time (Gemelli 1995: 42-44).

In his review, Braudel sketched out the preceding forty years of scholarship, noting with approval Julien's remark that '[1]e perfide Maghreb n'est pas moins hostile aux historiens qu'aux conquérants' and proceeds to describe the work of historians as a vast project of mapping and conquest. Indeed, he presented his review as an attempt 'to mark, after so much analytical work, the last line reached by the historical conquest in these fields [marquer, après tant de travaux d'analyse, la ligne dernière qu'atteint la conquète historique en ces domaines]' (Braudel 1933: 37-38). This is, says Braudel, 'an imperialism of History' [imperialisme historique]. By this he means that the work of historians in North Africa runs alongside the wider 'French work in North Africa' [l'oeuvre francaise, en Afrique du Nord] and the History that Julien has produced tells Braudel that the French can regard their past activities in North Africa 'sans remords'. The writing of History is thus a part of the wider apparatus of French governance:

La conquête historique du Maghreb est bien une lutte, aussi dure que les autres, là contre la silence ou la rareté de nos renseignements, là contre les hésitations du raisonnement ou la déformation sentimentale de nos jugements. (Braudel 1933: 5253; Hannoum 2008: 108; emphasis added)

Braudel's implication in colonial humanism is present in the metaphors of conquest and mapping that he uses to describe the acquisition of knowledge about the past. Professional ambition and republicanism led the leaders of the Annales school to align themselves with the colonial policies of the Third Republic (Reynaud Paligot 2009: 142-143). These concerns 
also shape Braudel's own conception of French colonialism and are visible, for example, in the way he praises French engagement with indigenous communities in Algeria (Merkel 2017: 147-148). In this review, historical knowledge is explicitly integrated in to the 'other conquests' that have shaped the economic relationships and governing structures of the French empire (Reynaud Paligot 2009: 142). History is a struggle to assert 'rationality' and thereby to know the past. Braudel's review intertwines the epistemological structures of History - with its rationality and universal scope - with the material, economic structures of imperial rule.

Braudel noted that his experiences of imprisonment during the Second World War played a formative role in the writing of La Mediteranée, but it is clear that the methodology of the book was already coalescing in the 1930s (Braudel 1999: 496). This review of Julien shows the ways in which the production of History was determined by its colonial context. This is most obvious in the way that Braudel explicitly places knowledge production alongside the other conquests necessary to accomplish the 'French work' in Algeria. This assertion carries with it a host of claims about the relationship of the present to the past, the nature of the modern, and how the past can be represented by the historian. The colonial context is also present in the way that the study of History is positioned as both universal and particular. It is universal because it is rooted in rationality, transcending the localised histories of Ibn Khaldun and others. But it is also particular in the way that it is focussed on the specific ways that different human societies are shaped by their geographical context. This dance between the universal and the particular is a key feature of colonial humanism (Wilder 2005: 11-15). This is what Brown took from Braudel: this way of conceptualising the time and space of the Mediterranean. As Braudel's review of Julien indicates, however, this approach was itself shaped by the imperial ambitions of the Third Republic and colonial humanism.

\section{Culture: Henri Marrou and the development of his reading of ancient culture}

Shifts in the geographical imagination allowed Brown to conceptualise the space of late antiquity, but it was through the prism of culture that he could imagine its people. As one recent study has put it: 'one of the defining features of this field has been its attention to culture. Culture stands at the productive center of the modern historiographic creation of "late antiquity"' (Jacobs 2016: 266). A focus on the cultural life of late Roman people was key to Brown's re-evaluation of the period. Although this methodological commitment was influenced by contemporary anthropology, it was also indebted to accounts of culture and 
change produced by French academics in the 1930s. The model of culture that emerged in these earlier works was a product of the discourses of colonial humanism.

Right at the beginning, Brown's readers are told that The World of Late Antiquity is a 'study of social and cultural change' (Brown 1971: 7) and he goes on to remind them that the Roman Empire of around 200 was ruled 'by an aristocracy of amazingly uniform culture, taste, and language'(Brown 1971: 14). This focus on culture was a key element of Brown's work at this time. For example, his 1971 article 'The Rise and Function of the Holy Man' defines itself as an intervention in the history of 'Late Roman culture' (Brown 1982: 82). A large influence in this turn to culture was the work of Mary Douglas (Brown 1982: 93, n.164; Brown 2003: 2). In a later reflection, Brown also identified the work of the French historian Henri-Irénée Marrou as an important influence on the ways that he imagined people's lives in the late Roman world. He noted that, after reading Marrou's work, '[a]ncient civilisation was not a drained corpse, that could be briskly dragged from the stage' (Brown 1997: 10). The influence of Marrou is acknowledged, for example, in an article from the early 1980s. In this article, Brown places the late Roman phenomenon of holy people within wider contemporary models of education and erudition. As he does so, he notes that Marrou has defined the late Roman world as 'The Civilisation of Paideia' (Brown 1983: 1). The cultural role played by paideia (education) was, for Brown, a keystone in the edifice of late antiquity that he was constructing in the 1980s. It is here that the influence of Marrou is most clearly detectable.

When he analysed the functional role played by elements of late Roman culture - such as the Holy Man - Brown was clearly influenced by contemporary anthropologists like Douglas. But the turn to culture as a specific area of enquiry was, at least partially, a response to his reading of Marrou. Marrou's influence was lasting, most notably in Brown's focus on paideia as a keystone of late antique culture. Marrou's model of education and culture has its roots in his work of the 1930s and 1940s. It is present in his monograph on Augustine, originally written in the 1930s and republished in late 1949. It is also fundamental to the long history of education that Marrou published in 1948. As Brown acknowledges, these two books helped him to describe and analyse the lives of people in the late Roman world. Marrou's work, however, was part of a much wider debate in France about the nature of culture and civilisation. This debate, focussed as it was on ways to differentiate and thereby understand different human societies, was tightly bound into the colonial humanism of the Third Republic. 
Marrou's doctoral dissertation was produced in Italy and published in 1938 as Saint Augustin et la fin de la culture antique (Marrou 1938). At the beginning of the book, Marrou expanded the definition of the word 'culture' in French. He said it referred to 'the life of the spirit' and 'the intellectual aspect of a civilisation'. In this study, Augustine was the bridge between the late Roman world and the Medieval, for in Augustine's writings the techniques of classical culture are subordinated to the needs of the Church and the future medieval world is brought into existence (Vessey 1998: 385). By the time the book was republished in 1949, Marrou had revised his reading of Augustine (Marrou 1949). He no longer saw in Augustine the end of the Classical and the beginning of the Medieval; now there was something distinctive that Augustine shared with others of his age, a common 'life of the spirit' that Marrou termed the 'culture of the Theopolis' (Marrou 1949: 696; Vessey 1998: 389). Brown said, of reading this 'Retractatio', 'I was thrilled by the glimpse [...] offered of the sheer resilience of preChristian society and culture at the very moment of the triumph of the Christian Church within the Roman Empire' (Brown 1997: 11).

Marrou's 1949 addendum to his work on Augustine is complemented by his book on education, which was published the year before (Marrou 1948). In the introduction to this book, he laid out his understanding of the importance of education: 'everything of importance in our own civilization derives from [the ancient world]'. Each civilization, he continued, could be distinguished because it had a particular form that was unique to it:

l'éducation est la technique collective par laquelle une société initie sa jeune génération aux valeurs et aux techniques qui caractérisent la vie de sa civilisation. L'éducation est donc une phénomène secondaire et subordonné par rapport à celle-ci dont, normalement, elle représente comme un résumé et une condensation (je dis normalement, car il existe des sociétés illogiques qui imposent à la jeunesse une éducation absurde sans rapport avec la vie [...]) Cela suppose évidement un certain décalage dans le temps : il faut d'abord qu'une civilisation atteigne sa propre Forme avant de pouvoir engendrer l'éducation qui la reflétera. (Marrou 1948 : 17)

For Marrou, the study of education is important because it presents to the historian a distillation of the central ideals that distinguish one civilisation from another. Although classical education came to flourish in the decades following Alexander the Great and Aristotle, 'this evolution was already present from the beginning' ('cette évolution est donnée dès le début comme acquise'); the characteristic developments of Hellenistic civilisation were 
merely the working-out of elements that had been present from the earliest stirrings of classical culture (Marrou 1948: 139). Marrou's model of historical change here is teleological. The study of education offers a sight-line into the heart of a civilisation's unique way of seeing and understanding the world. It shows the conceptual and intellectual structures that lie latent, only becoming visible as they're articulated in the words of pedagogues.

Differences between these conceptual and intellectual structures are what distinguish civilisations from each other. Thus, for example, Marrou insisted that it was incorrect to speak of a Roman civilisation separate from the Hellenistic world; the educational forms followed by the Romans were merely a continuation of those initiated in the Hellenistic, which indicated that they were part of the same civilisation. 'Italy, and through her the whole of the Latinised West, was annexed to Hellenistic civilisation' ('l'Italie, puis, par elle, tout l'Occident latinisé, ont été annexés à l'aire de la civilisation hellénistique') (Marrou 1948: 140). As this common Hellenistic tradition took root, argues Marrou, so the divisions in the ancient world became less pronounced:

Qu'est-ce qui fait, désormais, l'unité de ce monde grec [...] ? Moins que jamais, c'est le sang [...] ce ne peut être que le fait de communier en un même idéal, dans la même pensée concernant la finalité essentielle de l'homme et les moyens d'atteindre celle-ci, en un mot la communauté de civilisation ou, pour mieux dire, de culture. (Marrou 1948: 144)

Separate groups of people are now drawn together into a common civilisation that transcends differences of 'blood'. In this way, he says, 'l'hellénisme s'incorpore et s'assimile tant d'éléments d'origine étrangère' (Marrou 1948: 144). Culture, as Marrou defines it here, carries a personalist nuance. By this he means that 'la culture' does not designate a particular form of social life - such as, say, 'the city' - but rather a common understanding of humanity and the nature of human perfection. What bound the Hellenistic and Roman world into one common culture, what enabled the assimilation of elements foreign to this culture, was that they had all received 'la meme formation orientée à cette fin commune, - la même education' (Marrou 1948: 144). This was, then, a civilisation defined by its education: the civilisation of paideia.

Marrou therefore sketches out a common lineage for Hellenistic education. Coming to fullness in the decades after Alexander and Aristotle, it succeeded in binding together the 
whole of the Mediterranean, integrating, through Rome, Western Europe. A shared ideal of humanity and its end - 'la culture' - transcends differences of blood between peoples. This history means, he says, that the study of ancient education has a particular importance for French people:

si l'antiquité a fécondé tout notre tradition européenne [...] c'est dans la mesure où leur apport créateur a été recueilli, intégré et transmis par cette tradition classique à laquelle la civilisation hellénistique a conféré sa Forme et dont l'éducation hellénistique représente la synthèse et comme la symbole. (Marrou 1948 : 142)

Divisions of 'blood' can be dissolved through the careful induction of people into a common paideia. The European present, culture, and periodization, were the key conceptual touchstones for Marrou's work on education. Brown was to develop a very different way of understanding culture, but he retained from Marrou this methodological centring of culture and periodization.

The discussion of culture and civilisation that Marrou follows in his work of the 1930s and 1940s parallels wider debates. The circle of French Catholics in which Marrou moved during this period was heavily influenced by the work of Jacques Maritain (Riché 2003: 36). In a series of notes written on retreat in late 1928 and early 1929, Marrou can be seen grappling with the relationship between contemporary French culture and his life as a Catholic (Marrou 2006: 81-86, 89). These reflections were to lead to Marrou's first monograph, his Fondements d'une culture chrétienne which was published in 1934 under the pseudonym of Henri Davenson (Davenson 1934).

This book was a manifesto for the post-war generation. Marrou argued that, for those who had been too young to fight for France, life could offer nothing more meaningful than a life selling coffee in Ethiopia or copra in the South Seas (Davenson 1934: 16). At a time of worldwide economic depression the young men of France find themselves clasped into an imperial world-system rooted in the social division of labour:

Nous sentions tout ce qu'il y avait de grand dans cette énorme machine qui a fait de l'humble travail un domaine aussi beau et aussi rationnellement organisé que celui de la géométrie grecque. Alors nous rêvions nous aussi d'avoir des lunettes d'écaille, et des secrétaires affairées, et de signer des télégrammes qui enverraient des cargos au 
delà de Suez [...] Jouer le jeu en pleine conscience, s'enivrer chaque jour de cette mystique des chiffres et de l'action. (Davenson 1934: 23)

Central to this book is the identification of an imperial geography of capitalism that takes in Suez, Ethiopia, India, and the South Seas. This 'enormous machine' is fundamentally antihumane. Fondements is focussed on tracing and then resisting this machine's pernicious effects. The social divisions of labour under imperial capitalism produce societies in which people are alienated from themselves and each other - an inhumanity that should be resisted. Positioning itself as an attempt to mitigate the alienation produced by capitalism, Marrou's work is typical of the turn towards the 'new humanism' that marked French intellectual culture during the 1930s (Debaene 2014: 121-124).

Marrou argues that this resistance must begin with a new way of imagining human beings and their place in the world. However, such a cultural renewal must also be culturally specific. For example, says Marrou, Gandhi seeks the renewal of India and he does it by subordinating his life to a Hindu metaphysics (Davenson 1934: 21-22). Marrou calls on his peers to follow the example of Saint Augustine, who renewed his culture by subscribing to a Christian metaphysics. Marrou develops in this book a notion of culture as the articulation of a shared intellectual spirit. This was the same definition he put forward in his later book on Saint Augustine. His work of the later 1930s, and its subsequent development in the five years after the war, begins here with this particular model of culture and civilisation.

The roots of Marrou's argument in this early book lie in the ethnological work of Marcel Mauss, whom he quotes approvingly at a couple of key points. At the opening of a discussion over the nature of civilisations and how they might be understood as a corporate whole Marrou quotes a number of lines from Mauss's 1929 paper on the definition of civilisation (Davenson 1934: 69). This paper was important for Mauss, offering a synthesis of his own work on the fact and notion of civilisation as it applied to the analysis of human society (Mauss 1968). In this paper, Mauss insisted that the notion of civilisation as it was used in popular discourse of the 1920s (e.g., in talk of a crisis of civilisation) was an illusion (Fournier 2006: 259). There was no common 'civilisation', he argued. Instead, there were broad commonalities of morality and aesthetics. Particular groups of people might manifest this morality or aesthetic sensibility in particular ways, in differences of dress, for example. Behind these distinctive features, or modes, or idiosyncrasies, there lay a common way of seeing the world that might be termed a 'civilisation' (Bert 2009: 131). Social life, in its 
material specificity, is contrasted with 'civilisation', which is a particular way of imagining the world; if civilisation is what is held in common by different peoples, then '[1]e domaine du social c'est le domaine de la modalité' (Mauss 1968).

This paper was part of a wider project. In the 1920s and 1930s, Mauss argued that there was no fundamentally superior civilisation. Instead, each society understood universal concepts, like the body or the gift, in culturally specific ways. While there was no one culture that was innately superior, Mauss said that the most stable communities were those which had enshrined the bonds of society in written law and citizenship, 'freely participating in the Idea guiding it' (Conklin 2013: 250-251). Mauss's ethnology therefore argued that no culture was inherently superior to another, but that the codification of rights in law rendered some societies more stable (Wilder 2005: 66-67). This model of culture and law cohered very closely with colonial humanism's own understanding of imperial rule and cultural difference.

In Fondements d'une culture chrétienne, Marrou draws on Mauss's 1929 essay to talk about the commonalities that bind different peoples together into a common civilisation. Quoting Mauss's 1929 paper at length, Marrou argues that what unites civilisations, what enables their identification and differentiation, is not the bodily differences proposed by racial theorists like Gobineau, or differences of material culture. Rather, 'ce qui donne à ces civilisations leur unité profonde, c'est toujours un ensemble d'idées, de croyances, senties et reçues comme vérité' (Davenson 1934 : 72). Thus, he says, one way of defining civilisations is by understanding them as sharing 'une certaine doctrine sur le monde, l'homme et la vie' (Davenson 1934: 73). Marrou returns to Mauss to note how this common way of viewing the world should be contrasted with the ways in which social rituals and material culture are markers of difference (Davenson 1934: 78-79). He cites the part of Mauss's essay which grapples with the difference between civilisation and social life. The emergence and meaning of particular social phenomena are arbitrary and human beings can only endure them, Marrou argues, but behind this arbitrary, shifting social swirl, there remain common ways of seeing the world and ascribing meaning to human life (Davenson 1934: 78-79). It is this commonality, persisting amid the chaos, that Marrou designates 'civilisation'.

Reflecting on Marrou's impact on his understanding of the later Roman world, Brown said:

A remarkable tradition of French liberal Catholic scholars had turned their attention since the late 1930s to the intimate links between late classical civilization and the thought-forms and culture of the great Christian writers of the Patristic age. This 
tradition gave me my first sighting of a pre-medieval Christianity, of unexpected warmth, richness and flexibility, and, above all, of a Christianity held at a safe distance from the present, by having been firmly planted back where it belonged, in its native, ancient soil (Brown 1997, 11).

Brown's work of the 1970s and 1980s drew on Marrou in the way that it focussed on the notion of paideia as the underlying bond that drew together the disparate social features of life in the late Roman world. Although Brown was to move away from Marrou's model of culture, incorporating a wider variety of sources from different regions of the late ancient world, he retained this emphasis on the binding power of paideia. Marrou's turn to paideia comes in his work of 1948 and 1949, which presented the Hellenistic world as a civilisation of paideia. This shift in Marrou's work rested on much earlier forays into the question of culture and civilisation that emerged in France in the late 1920s. As with other contributors to this debate, Marrou's engagement with the question of culture was always an attempt to think through the inhumane effects of a capitalist imperial economy. Marrou's engagement in this debate was to come in his first monograph, which shows his debt to Mauss. There is, then, a clear and direct link between debates on human culture and civilisation in the Third Republic and the importance of 'culture' as an analytic category in Brown's work of the 1970s and 1980s.

The Third Republic framed French culture in terms of its capacity to transcend cultural differences; inculcation into the republican humanism of France would ameliorate particular, local cultural differences. In this way, the colonial humanism of the Third Republic has close structural similarities to the model of Hellenistic civilisation that Marrou puts forward in his History of Education. Marrou's model of education and late Roman civilisation replicated a colonial humanism that argued that alterity could be absorbed into the French republican tradition as long as the colonial subject conformed to the paideia of France. Those who did not carry this paideia were not part of the humanist tradition. As Marrou says, 'it is remarkable that when Varro and Cicero have to translate paideia, they will choose the Latin word humanitas' (Marrou 1948: 144). The inhumane effects of imperial capitalism can only be ameliorated through inculcation into paideia. Marrou's texts lay out clearly the way that he thinks ancient education functioned. In so doing, he naturalises the imperial policies of France, making them seem one more example of the evolution of civilisations in the Mediterranean. Recognising this opens up a couple of interesting ways to work over our own late antique imaginations. 


\section{Conclusion}

'Late antiquity' is a way of imagining and representing the world. It orders the world within a specific matrix of time and space, combined with a particular way of evaluating human difference through the prism of culture. One of the unusual characteristics of this field is the way that representations of the late antique past in historians' writings play, more or less explicitly, between the late antique and the modern. This 'rhetoric of modernity' has been noted in a number of historiographical studies but these studies locate the modernity of late antiquity in different places. Sometimes the field of late antiquity is modern in its refusal to explain social change through crisis and catastrophe. Sometimes it is modern because it focuses on fundamental similarities between cultures, rather than on human difference. Sometimes it is modern because key components of modernity are said to originate in late antiquity. Generally, late antiquity's modernity is positioned as a product of the ideological commitments of a liberal, left-leaning academy. In all cases, the definition of 'modern' has consequences for how late antiquity is represented by the historian.

In his account of the historian's work, Eelco Runia uses the concept of parallel processing to describe the ways in which the past becomes present in the work of historians. The way that historians do history, their academic practice, their epistemological commitments, these are for Runia manifestations of wider anxieties within the society that the historian lives. The way that a historian imagines the past is trammelled by these contemporary anxieties which are displaced into their work. As Jameson argued, the development of imperial economies catalysed a crisis in the way that the Métropole represented itself to itself. Literary modernism emerged as a way to reconcile or ameliorate this crisis in representation. For Jameson, the colony figures as the hidden underside of modernity, an other that constitutes the Métropole but remains always beyond the limits of representation. This crisis of representation is detectable when the totality of realist representations of the world breaks down. One place in which this commonly happens is in the descriptions of space in the modernist novel.

As Brown has noted, the emergence of late antiquity in his work was catalysed by the reception of two Francophone authors: Braudel and Marrou. From Braudel, Brown took a way of imagining space. The world of late antiquity coalesced for him around the Mediterranean, that area of connectivity, travel, and economic exchange. From Marrou, Brown took an invigorating approach to the social and cultural life of the late Roman world. After Marrou, there could be no lingering sense that the Roman world of the fourth and fifth 
centuries was a slowly decaying corpse. Instead, he showed Brown that something new and vibrant developed in these centuries: a civilisation of paideia, the Theopolis.

As this article has shown, the work of Braudel and Marrou is a product of a wider French conversation about how to imagine and govern the space and people of the French empire. This conversation, dubbed 'colonial humanism', differentiated human beings according to geography and culture. Brown took from Braudel an appreciation of the Mediterranean as a space of economic exchange and a bridge linking North Africa to Europe. As this article has shown, this aspect of Braudel's work was in place in 1933, before the publication of La Mediteranée. Moreover, this Mediterranean imagination was intertwined with the economic and cultural concerns of the Third Republic. The historian laboured alongside the other conquerors of the Maghreb and knowledge production was enfolded into the wider orders of production in the Third Republic.

Similarly, Marrou's account of culture and civilisation was but one small part in a general debate over these words that unfolded in France after 1918. This debate reached a high point around 1930, as can be seen in the work of Mauss. Marrou's own response to this is his pseudonymous 1934 book on Christian culture in which he draws on Mauss's ethnology to define culture as a common metaphysics. Culture and civilisation became key analytical concepts for Marrou, who continued to develop them in his work of the 1930s and 1940s. In all cases, however, he retained this focus on common ways of knowing and giving meaning to the world. This model of culture reappears in his 1948 book on education, a work in which he argued that paideia functioned to ameliorate differences of 'blood'. Education and culture were, for Marrou, a means of transcending human difference. As Mauss argued, while the world was made up of many civilisations, it was the republican nation state that offered the greatest stability to human society. In a similar way, Marrou's account of the civilisation of paideia demonstrates the power of education to inculcate others with the 'spirit' of a civilisation and thereby dissolve the destabilising threat of difference.

Brown drew on the work of Braudel and Marrou, but these men were themselves part of a wider project of French imperial imagining. If there is a 'rhetoric of modernity' operating in the discipline of Late Antiquity then we find it here: in the role of the colony as something critical to late antiquity's formation, just as the colony was critical to the formation of the modernist novel. As in the modernist novel, the colony is occluded. Its presence is detectable when Brown situates late antiquity in relationship to 'modern' European culture. To put it 
bluntly, late antiquity is modern because it was constituted in relationship with the colonial other, particularly Algeria. It remains modern to the extent that the constituting role of the colony is unacknowledged in the historiography of the field.

This article began by observing that the study of late antiquity is marked by a reflexivity over periodization and topography. There are endless debates in the historiography about what late antiquity is, about where its boundaries lie, and how it can be known. One way of breaking open this impasse might be to recognise that late antiquity itself emerges from the contradictions of the political economy of the Third Republic. Anxieties about what late antiquity is, about what defines late antique culture, these are the debates of colonial humanism displaced into a new context. The works of historians are ideological products that serve to discipline the past and ameliorate the contradictions in contemporary society. Despite their best efforts, however, the past does not stay disciplined and confined. Rather, it makes its presence felt in the gaps and stumblings in our accounts of history. It peeps out at us between the quotation marks that engulf the 'modern'.

\section{References}

Bert, J. (2009), 'Marcel Mauss et la notion de "civilisation"', Cahiers de recherche sociologique, 47, pp. 123-142.

Blais, H. and Deprest, F. (2012), 'The Mediterranean, a Territory between France and Colonial Algeria: Imperial Constructions', Revue européenne d'histoire, 19:1, pp. 3357.

Bowersock, G. W., Brown P. and Grabar, O. (1999), Late Antiquity: A Guide to the PostClassical World, Cambridge, Massachusetts: Harvard University Press.

Braudel, F. (1933), 'À propos de L'Histoire de l'Afrique du Nord de Ch. André Julien', Revue Africaine, 74: 1, pp. 37-53.

_ (1999), 'Personal Testimony', in Stuart Clark, (ed.), The Annales School: Critical Assessments. Volume II: The Annales School and Historical Studies, London: Routledge, pp. 491-508.

Brown, P. (1961a), 'Aspects of the Christianisation of the Roman Aristocracy', Journal of Roman Studies, 51: 1 and 2, pp. 283-305.

— (1961b), 'Religious Dissent in the Later Roman Empire: the Case of North Africa', History, 46: 157, pp. 83-191.

— (1967), Augustine of Hippo: A Biography, London: Faber and Faber.

_ (1971), The World of Late Antiquity, London: Thames and Hudson. 
_ (1982), 'The Rise and Function of the Holy Man in Late Antiquity', in Peter Brown (ed.), Society and the Holy in Late Antiquity, Berkeley: University of California Press, pp. 103-152.

_ (1983), 'The Saint as Exemplar in Late Antiquity', Representations, 2, pp. 1-25.

_ (1988), ‘† Arnaldo Dante Momigliano, 1908-1987', Proceedings of the British Academy, 74, pp. 405-442.

_ (1997), 'The World of Late Antiquity Revisited', Symbolae Osloenses, 72:1, pp. 5-30.

_ (2003), 'A Life of Learning: Charles Homer Haskins Lecture for 2003', ACLS Occasional Paper, 55, pp. 1-22.

Cameron, A. (1993), The Mediterranean Wolrd in Late Antiquity AD 395-600, London and New York: Routledge.

Conklin, A. L. (2013), In the Museum of Man: Race, Anthropology, and Empire in France, 1850-1950, Ithaca and London: Cornell University Press.

Cooper, F. (2005), Colonialism in Question: Theory, Knowledge, History, Berkeley and London: University of California Press.

Cordileone, D. R. (2014), Alois Riegl in Vienna 1875-1905: An Institutional Bibliography, Studies in Art Historiography, Farnham and Burlington, Vermont: Ashgate.

Daix, P. (1995), Braudel, Paris: Flammarion.

Davenson, H. (1934), Fondements d'une culture chrétienne, Paris: Bloud et Gay.

Davis, D, K. (2007), Resurrecting the Granary of Rome: Environmental History and French Colonial Expansion in North Africa, Athens, Ohio: Ohio University Press.

Debaene, V. (2014), Far Afield: French Anthropology between Science and Literature (trans. J. Izzo), Chicago and London: University of Chicago Press.

Deprest, F. (2010), 'Fernand Braudel et la géographie 'algérienne’: aux sources coloniales de l'histoire immobile de la Méditerranée?', Matériaux pour l'histoire de notre temps, 3: 99, pp. 28-35.

DeSilvey, C. and Edensor T. (2012), 'Reckoning with Ruins', Progress in Human Geography 37:4, pp. 1-21.

Elsner, J. (2002), 'The birth of Late Antiquity: Riegl and Strzygowski in 1901', Art History, 25:3, pp. 358-379.

Ford, C. (2015), 'The Inheritance of Empire and the Ruins of Rome in French Colonial Algeria', Past and Present 226:10, pp. 57-77. 
Foucault, M. (1977), 'Nietzsche, Genealogy, History', in D. F. Bouchard, (ed.), Language, Counter-Memory, Practice: Selected Essays and Interviews, Ithaca, New York: Cornell University Press.

Fournier, M. (2006), Marcel Mauss: A Biography, Princeton, New Jersey: Princeton University Press.

Gautier, E. F. (1927), L'islamisation de l'Afrique du Nord: Les siècles obscurs du Maghreb, Paris: Payot.

— (1932), Genséric, roi des Vadales, Paris: Payot.

Gemelli, G. (1995), Fernand Braudel. Paris: Éditions Odile Jacobs.

Giardina, A. (2013), 'Explosion of Late Antiquity', in A. Cameron, (ed.), Late Antiquity of the Eve of Islam, London and New York: Routledge, pp. 1-23.

Hannoum, A. (2008), 'The Historiographic State: How Algeria once became French', History and Anthropology, 19: 2, pp. 91-114.

Hannoum, A. (2010), Violent Modernity: France in Algeria, Cambridge, MA and London: Harvard University Press.

Hell, J. (2009), 'Katechon: Carl Schmitt's Imperial Theology and the Ruins of the Future', Germanic Review, 84: 4, pp. 283-326.

Icke, P. (2011), Frank Ankersmit's Lost Historical Cause: A Journey from Language to Experience, London and New York: Routledge.

Jacobs, A. S. (2016), Epiphanius of Cyprus: A Cultural Biography of Late Antiquity, Oakland, California: University of California Press.

James, E. (2008), 'The Rise and Function of the Concept "Late Antiquity", Journal of Late Antiquity, 1: 1, pp. 20-30.

Jameson, F. (1990), 'Modernism and Imperialism', in T. Eagleton, F. Jameson and E. Said, Nationalism, Colonialism, and Literature, Minneapolis and London: University of Minnesota Press.

LaCapra, D. (2001), Writing History, Writing Trauma, Baltimore, MD: Johns Hopkins University Press.

Liebeschuetz, J. H. W. G. (2001a), 'Late Antiquity and the Concept of Decline', Nottingham Medieval Studies, 45, pp. 1-11.

_ (2001b), 'The Uses and Abuses of the Concept of "Decline", or Was Gibbon Politically Incorrect?', in L. Lavan, (ed.), Recent Research in Late Antique Urbanism, Journal of Roman Archaeology Supplement 42, Portsmouth, Rhode Island, pp. 238-245. 
_ (2003), 'Late Antiquity, the Rejection of “Decline”, and Multiculturalism', Atti dell'Accademia Romanistica Costantiniana. XIV Convegno Internazionale in Memoria di Guglielmo Nocera, Napoli: Edizioi Scientifiche Italiane, pp. 639-652.

Lorcin, P. (2002), 'Rome and France in North Africa: Recovering Colonial Algeria's Latin Past', French Historical Studies, 25: 2, pp. 295-329.

Marcone, A. (2008), ‘A Long Late Antiquity?: Considerations on a Controversial Periodization', Journal of Late Antiquity 1: 1, pp. 4-19.

Markus, R. A. (2009), 'Between Marrou and Brown: Transformations of Late Antique Christianity', in P. Rousseau and M. Papoutsakis, (eds), Transformations of Late Antiquity: Essays for Peter Brown, Burlington, Vermont: Ashgate, pp. 1-14.

Marrou, H. I. (1938), Saint Augustin et la fin de la culture antique, Paris: De Boccard.

— (1948), Histoire de l'éducation dans l'antiquité. Paris: Éditions du Seuil.

_ (1949), 'Retractatio', in Saint Augustin et la fin de la culture antique, $2^{\text {nd }}$ edn, Paris: De Boccard.

— (2006), Carnets posthumes, Paris: Cerf.

Mauss, M. (1968), 'Les civilisations. Éléments et formes', in M. Mauss, Représentations collectives et diversité des civilisations. Oeuvres II (ed. V. Karady), Paris: Les Éditions de Minuit, pp. 456-479.

Mazzarino, S. (1942), Stilicone: la Crisi Imperiale Dopo Teodosio, Rome: Angelo Signorelli. Merkel, I. (2017), 'Fernand Braudel, Brazil, and the Empire of French Social Science: Newly Translated Sources from the 1930s', French Historical Studies, 40:1, pp. 129-160.

Mignolo, W. D. (2000), Local Histories/Global Designs: Coloniality, Subaltern Knowledge, and Border Thinking, Princeton and Oxford: Princeton University Press.

_ (2002), 'The Geo-Politics of Knowledge and Colonial Difference', The South Atlantic Quarterly, 101: 1, pp. 57-96.

Olin, M. (1994), 'Alois Riegl: The Late Roman Empire in the Late Hapsburg Empire', Austrian Studies 5, pp. 107-120.

Quijano, A. (2007), 'Coloniality and Modernity/Rationality', Cultural Studies 21: 2-3, pp. $168-178$.

Reynaud-Paligot, C. (2006a), La Republique raciale: Paradigme raciale et idéologie républicaine (1860-1930), Paris: Presses Universitaires de France.

— (2006b), 'Usages coloniaux des représentations raciales (1880-1930)', Cahiers d'histoire, 99, https://journals.openedition.org/chrhc/813. Accessed 12 March 2018. 
—_ (2009), 'Les Annales de Lucien Febvre à Fernand Braudel: Entre épopée coloniale et opposition Orient/Occident', French Historical Studies, 32: 1, pp. 121-144.

Riché, P. (2003), Henri Irénée Marrou, historien engagé. Paris: Cerf.

Riegl, A. (1901), Die spätrömische Kunst-Industrie nach den Funden in Österreich-Ungarn. Vienna: K. K. Hof- \& Staatadruckerei.

—_ ([1901] 1985), Late Roman Art Industry (trans. R. Winkes), Rome: Giogio Bretschneider.

Runia, E. (2014), Moved by the Past: Discontinuity and Historical Mutation, New York: Columbia University Press.

Sibeud, E. (2002), Une science impériale pour l'Afrique? La construction des savoirs africanistes en France 1878-1930, Paris: Èditions de l'École des Hautes Études en Sciences Sociales.

Strachan, J. (2011), 'The Colonial Cosmology of Fernand Braudel', in Martin Thomas, (ed.), The French Colonial Mind : Mental Maps of Empire and Colonial Encounters, Lincoln: University of Nebraska Press, pp. 71-95.

Testa, R. L. (2017), 'Introduction,' in R. Lizzi Testa, (ed.), Late Antiquity in Contemporary Debate, Newcastle-Upon-Tyne: Cambridge Scholars Publishing, pp. 7-49.

Vessey, M. (1998), 'The Demise of the Christian Writer and the Remaking of "Late Antiquity": From H.-I. Marrou’s Saint Augustine (1938) to Peter Brown’s Holy Man (1983)', Journal of Early Christian Studies, 6: 3, pp. 377-411.

Wilder, G. (2005), The French Imperial Nation-State: Negritude and Colonial Humanism Between the Two World Wars, Chicago, Illinois and London: University of Chicago Press.

Wood, I. (2013), The Modern Origins of the Early Middle Ages, Oxford: Oxford University Press.

Young, R. (1990), White Mythologies: Writing Histories and the West, London: Routledge. 